\title{
Inherited Selective Intestinal Cobalamin Malabsorption and Cobalamin Deficiency in Dogs
}

\author{
JOHN C. FYFE, URS GIGER, CHARLES A. HALL, PETER F. JEZYK, SHERRY A. KLUMPP, \\ JOEL S. LEVINE, AND DONALD F. PATTERSON \\ Sections of Medical Genetics [J.C.F, U.G., P.F.J., D.F.P.] and Pathology [S.A.K.], School of Veterinary Medicine, \\ University of Pennsylvania, Philadelphia. Pennsylvania 19104; the Nutrition Laboratory for Clinical Assessment \\ and Research, Veterans Administration Medical Center, Albany, New York 12208 [C.A.H.]; and University of \\ Colorado Health Sciences Center, Denver, Colorado 80262 [J.S.L.J
}

\begin{abstract}
Inherited selective intestinal malabsorption of cobalamin (Cbl) was observed in a family of giant schnauzer dogs. Family studies and breeding experiments demonstrated simple autosomal recessive inheritance of this disease. Affected puppies exhibited chronic inappetence and failure to thrive beginning between 6 and 12 wk of age. Neutropenia with hypersegmentation, anemia with anisocytosis and poikilocytosis, and megaloblastic changes of the bone marrow were present. Serum Cbl concentrations were low, and methylmalonic aciduria and homocysteinemia were present. Parenteral, but not oral, cyanocobalamin administration rapidly eliminated all signs of $\mathrm{Cbl}$ deficiency except for low serum $\mathrm{Cbl}$ concentrations. $\mathrm{Cbl}$ malabsorption in affected dogs was documented by oral administration of $\left[{ }^{57} \mathrm{Co}\right]$ cyanocobalamin with or without simultaneous oral administration of intrinsic factor or normal dog gastric juice. Quantitation and function studies of intrinsic factor and transcobalamin-II from affected dogs revealed no abnormality. Other gastrointestinal functions and ileal morphology were normal, indicating a selective defect of $\mathrm{Cbl}$ absorption at the level of the ileal enterocyte. Immunoelectron microscopy of ileal biopsies showed that the receptor for intrinsic factor-Cbl complex was absent from the apical brush border microvillus pits of affected dogs. This canine disorder resembles inherited selective intestinal $\mathrm{Cbl}$ malabsorption (Imerslund-Gräsbeck syndrome) in humans, and is a spontaneously occurring animal model of early onset Cbl deficiency. (Pediatr Res 29: 2431,1991 )
\end{abstract}

\section{Abbreviations}

Cbl, cobalamin

IF, intrinsic factor

IF-Cbl, intrinsic factor-cobalamin complex

TC-II, transcobalamin-II

$\mathrm{CN}-\mathrm{Cbl}$, cyanocobalamin

$\left[{ }^{57} \mathrm{Co}\right] \mathrm{CN}-\mathrm{Cbl}$, radioisotopically labeled cyanocobalamin

UCBC, unsaturated cobalamin binding capacity

MMA, methylmalonic acid

THCys, total homocysteine

Received June 1, 1990; accepted August 13, 1990.

Correspondence and reprint requests: John C. Fyfe, D.V.M., Section of Medical Genetics, School of Veterinary Medicine, University of Pennsylvania, 3850 Spruce Street, Philadelphia, PA 19104-6010

Supported by the NIH University of Pennsylvania Human Genetics Center (NIH Grant GM 32592), the National Referral Center for Animal Models of Human Genetic Disease (NIH Grant RR 02512), the Mrs. Cheever Porter Foundation, and the Lucille B. Markey Charitable Trust.
Dietary Cbl absorption is a complex and highly specific process (1). Cbl is freed from foodstuffs and binds to IF, a glycoprotein produced by the gastric mucosa and, in dogs, also by the pancreatic duct epithelium $(2,3)$. IF-Cbl complex binds specifically to a receptor in the microvillus pits of enterocytes lining the ileum (4). Transcytosis of Cbl subsequent to IF-Cbl receptor binding is a poorly understood process, but newly absorbed $\mathrm{Cbl}$ is found in portal circulation bound to TC-II for transport to tissues. Several inherited defects causing selective $\mathrm{Cbl}$ malabsorption and life-threatening $\mathrm{Cbl}$ deficiency in the first few years of life have been described in humans. These include secretion of insufficient or abnormal IF (5-7) and selective intestinal malabsorption of $\mathrm{Cbl}(5,8-10)$. TC-II deficiency is also associated with $\mathrm{Cbl}$ malabsorption, but the greater severity and earlier onset of clinical signs of this disease are related primarily to impaired transport of Cbl between tissues (11). The molecular or cellular defects causing selective intestinal $\mathrm{Cbl}$ malabsorption are unknown.

In our report, we describe clinical, metabolic, pathologic, and genetic features of inherited selective intestinal $\mathrm{Cbl}$ malabsorption in a large family of dogs. We also provide immunohistochemical evidence that absence of the receptor for IF-Cbl complex from the ileal apical brush border is the cause of $\mathrm{Cbl}$ malabsorption in this family of dogs.

\section{MATERIALS AND METHODS}

Animals. Seventeen affected dogs were studied. Detailed clinical and laboratory descriptions of the proposita and a related purebred giant schnauzer have been published (12). Eight offspring of a mating of those two dogs and seven mixbred offspring of $F_{1}$-backcross and $F_{2}$ matings were produced. Clinically normal littermates (obligate heterozygotes from $F_{1}$-backcross matings) served as controls in metabolic and hematologic studies. In Cbl absorption tests, five normal dogs (two standard poodles, one beagle, and two keeshonds) that were 15-26 mo old, weighing $11-31 \mathrm{~kg}$, served as controls. The dogs were maintained in the facilities of the University of Pennsylvania Unit of Laboratory Animal Resources, where they were allowed water ad libitum and fed a complete and balanced, commercial canine maintenance diet (Lab Canine Diet no. 5006, Ralston-Purina Co., St. Louis, MO). Puppies were weaned at 1 mo of age, and lactating bitches and puppies under 6 mo of age were fed a commercial puppy diet (Purina Puppy Chow, Ralston-Purina Co.) supplemented with canned meat (Big Bet, Big Bet Pet Foods, Dublin, PA). Affected dogs exhibiting clinical, hematologic, and metabolic signs of $\mathrm{Cbl}$ deficiency received $370-740 \mathrm{nmol}(0.5-1.0$ $\mathrm{mg}$ ) of $\mathrm{CN}-\mathrm{Cbl}$ intramuscularly as needed to maintain remission of clinical and laboratory abnormalities. All experimental protocols were approved by the Institutional Animal Care and Use Committee of the University of Pennsylvania. 
Reagents. $\left.{ }^{57} \mathrm{Co}\right] \mathrm{CN}-\mathrm{Cbl}(300 \mu \mathrm{Ci} / \mathrm{nmol})$ was obtained from Amersham Corp., Inc., Arlington Heights, IL. Crystalline CN$\mathrm{Cbl}$, cyanocobinamide, Sepharose-bound $\mathrm{Cbl}$, and practical grade porcine secretin were obtained from Sigma Chemical Co., St. Louis, MO. Reagents used in $\mathrm{Cbl}$ absorption studies in vivo were gelatin capsules each containing $0.56 \mu \mathrm{Ci}$ of $\left[{ }^{57} \mathrm{Co}\right] \mathrm{CN}-\mathrm{Cbl}$ $(1.14 \mu \mathrm{Ci} / \mathrm{nmol})$, gelatin capsules each containing one unit $(\mathrm{Na}-$ tional Formulary-XI) of porcine IF, a reference solution of $\left[{ }^{57} \mathrm{Co}\right]$ $\mathrm{Cl}_{2}$, and unlabeled $\mathrm{CN}-\mathrm{Cbl}$ for injection (Rubratope-57 Diagnostic Kit). These and cholecystekinin (Kinevac) were obtained from Squibb Diagnostics, New Brunswick, NJ. Rabbit anti-dog ileal IF-Cbl receptor serum was the generous gift of Dr. Bellur Seetharam, Medical College of Wisconsin, Milwaukee.

Hematologic and metabolic studies. Complete blood counts were done by routine methods. Bone marrow aspirates and core biopsy specimens were collected from the iliac crest under ultrashortacting barbiturate anesthesia. Serum Ig concentrations were measured by radial immunodiffusion using canine-specific reagents. Serum $\mathrm{Cbl}$ and folate concentrations were measured by a commercial radiobinding assay (Quantaphase $\mathrm{B}_{12} /$ Folate Radioassay, Bio-Rad, Hercules, CA)

Urinary organic acids were analyzed by gas-liquid chromatography and mass spectrometry after extraction and conversion to trimethylsilyl derivatives, with hexadecandioic acid as internal standard. Free serum and urinary amino acids were separated and quantified by ion-exchange chromatography using a Beckman model 7300 amino acid analyzer (Beckman Instruments, Palo Alto, CA) with lithium citrate buffers. Total serum homocysteine (THCys=free + disulfide bound + protein bound) was measured by a previously described method of capillary gas chromatography-mass spectrometry with selective ion monitoring and deuterated homocysteine as an internal standard (13). Endogenous creatine clearance (14) and 24-h protein excretion (15) were determined by reported methods.

Cbl absorption studies. Three Cbl-treated affected dogs, one heterozygous dog, and five normal control dogs underwent radiolabeled-Cbl absorption tests. The proposita was $51 \mathrm{mo}$ old and weighed $32 \mathrm{~kg}$. A heterozygous normal and two affected $F_{1}-$ backcross littermates were 9 mo old and weighed $32-38 \mathrm{~kg}$. Dogs were housed separately in cages with grated floors, and received $740 \mathrm{nmol}(1 \mathrm{mg})$ of CN-Cbl intramuscularly 4 and $2 \mathrm{~d}$ before starting the study. They were fasted for $12 \mathrm{~h}$ before each phase of study.

Intestinal absorption of $\mathrm{Cbl}$ was assessed by oral administration of $0.49 \mathrm{nmol}(0.66 \mu \mathrm{g})\left[{ }^{57} \mathrm{Co}\right] \mathrm{CN}$-Cbl alone (phase I) or with simultaneous oral administration of IF or normal dog gastric juice (phase II). In phase I, a single capsule of $\left[{ }^{57} \mathrm{Co}\right] \mathrm{CN}-\mathrm{Cbl}$ was administered orally to each dog, and $2 \mathrm{~h}$ later, $740 \mathrm{nmol}(1 \mathrm{mg})$ of unlabeled $\mathrm{CN}-\mathrm{Cbl}$ was administered intramuscularly. The dogs were fed at that time and every $12 \mathrm{~h}$ thereafter. Blood samples were collected in heparinized tubes at the time of $\left[{ }^{57} \mathrm{Co}\right]$ $\mathrm{CN}-\mathrm{Cbl}$ administration and repeatedly thereafter for $24 \mathrm{~h}$. For 6 d, all feces were collected immediately when passed to prevent contamination with urine. Phase II tests in the three affected dogs and the heterozygous dog began $10 \mathrm{~d}$ after the beginning of the phase I. Phase II was done identically to phase I except that each dog received two units of IF orally with a capsule of $\left[{ }^{57} \mathrm{Co}\right]$ $\mathrm{CN}-\mathrm{Cbl}$. Ten $\mathrm{d}$ after the beginning of phase II, phase II was repeated in two of the affected dogs and the heterozygous dog as before, except that $130 \mathrm{~mL}$ of normal dog gastric juice was administered with the $\left.{ }^{57} \mathrm{Co}\right] \mathrm{CN}-\mathrm{Cbl}$.

The radioactivity of 2.4-mL aliquots of each plasma sample was determined in a gamma counter and expressed as the fraction of the administered dose in the calculated total plasma volume ( 0.05 of total body weight). For determination of fecal excretion of radioactivity, stools were compressed into even layers in the bottom of cylindrical cardboard containers. The height of each fecal layer was recorded, and the radioactivity of each container of feces was determined in a deep-well gamma counter. A linear correction factor was calculated to correct for variable fecal sample geometry by counting $10 \mathrm{~mL}$ of $\left[{ }^{57} \mathrm{Co}\right] \mathrm{Cl}_{2}$ reference solution diluted with varying volumes of tap water. Fecal excretion of $\left[{ }^{57} \mathrm{Co}\right]$ was expressed as the fraction of the administered dose.

IF and TC-II characterization. Gastric juice was collected through a fiberoptic endoscope from anesthetized dogs with or without pentagastrin administration $(6 \mu \mathrm{g} / \mathrm{kg}$ body weight). Aliquots were taken for gastric acid titration and the remaining gastric juice was immediately chilled and depepsinized by raising the $\mathrm{pH}$ to 10.0 for $20 \mathrm{~min}$ with $2 \mathrm{M} \mathrm{NaOH}$. After neutralization to $\mathrm{pH} 7.2$ with $2 \mathrm{M} \mathrm{HCl}$, gastric juice was stored at $-20^{\circ} \mathrm{C}$. Pancreatic juice was collected essentially as described (16). We modified the procedure by collecting pancreatic secretions for 6 $h$ under continuous i.v. infusion of 1 unit secretin $/(\mathrm{kg} \cdot \mathrm{h})$ and $0.1 \mu \mathrm{g}$ cholecystekinin $/(\mathrm{kg} \cdot \mathrm{hr})$. Two $\mathrm{mM}$ phenylmethylsulfonylfluoride (final concentration) was added to collection tubes before sample collection.

Serum, gastric juice, and pancreatic juice UCBC were determined by modification of the method of Gottlieb et al. (17). IF determinations were done by the cyanocobinamide-blocking assay of Begley and Trachtenberg (18). IF was purified from gastric and pancreatic juice samples essentially by the method of Allen and Mehlman (19), except that before application of clarified and buffered samples to the affinity column, non-IF Cbl-binding proteins were blocked with 1000 -fold excess of cyanocobinamide. Binding assays of purified IF to Triton X-100 extracts of tissue homogenates were performed by the method of Seetharam $e t$ al. (20). In vivo function of the affected dog's purified pancreatic IF was tested in normal dogs. At laparotomy, the lumen of a 30$\mathrm{cm}$ segment of ileum $(30 \mathrm{~cm}$ proximal to the ileocecal valve) was washed with $500 \mathrm{~mL}$ of warmed buffered electrolyte solution (Normosol-R, Abbott Laboratories, North Chicago, IL) with 10 mM Ca-gluconate added. The segment was isolated with Doyen's intestinal clamps, and a cannula was placed at the confluence of mesenteric veins draining the segment. A sample of $3.7 \mathrm{pmol}$ of affected dog IF bound to [ $\left[{ }^{57} \mathrm{Co}\right] \mathrm{CN}-\mathrm{Cbl}(0.75 \mu \mathrm{Ci})$ in $20 \mathrm{~mL}$ of the lavage solution was put into the lumen of the isolated segment through a 26-gauge needle. Seven hundred forty nmol $(1 \mathrm{mg})$ of unlabeled $\mathrm{CN}-\mathrm{Cbl}$ were given i.v. at the same time and intramuscularly $90 \mathrm{~min}$ later. Blood samples were taken from the mesenteric vein cannula at 30 -min intervals for $4 \mathrm{~h}$. Plasma radioactivity was determined in a gamma counter. In another dog, the same procedure was done except that $3.7 \mathrm{pmol}(0.75$ $\mu \mathrm{Ci})$ of free $\left[{ }^{57} \mathrm{Co}\right] \mathrm{CN}$-Cbl was placed in the isolated ileal segment.

Sephadex-G200 gel filtration of Cbl-binding proteins was performed by previously described methods (21). Serum samples for TC-II analysis were separated from blood cells by centrifugation immediately upon collection without anticoagulant. Cultured fibroblasts were derived from skin biopsies taken under local anesthesia. Fibroblast culture and TC-II function studies were performed as previously described (22). In brief, serum samples were labeled to excess with $\left[{ }^{57} \mathrm{Co}\right] \mathrm{CN}-\mathrm{Cbl}$, and free label was removed with albumin-coated charcoal to measure binding capacity. Flasks containing $3 \mathrm{~mL}$ minimal essential medium without FCS were seeded with $5 \times 10^{5}$ cells/flask of normal dog fibroblasts. Serum, with TC-II labeled to capacity, was added to each flask at $185 \mathrm{fmol}$ TC-II- $\left[{ }^{57} \mathrm{Co}\right] \mathrm{CN}-\mathrm{Cbl} / \mathrm{mL}$ of medium. Cells were cultured for $24 \mathrm{~h}$ at $37^{\circ} \mathrm{C}$, harvested with trypsin, suspended, washed, sonicated, and centrifuged. Radioactivity of each fraction was determined at each step. Cell-associated label resisting trypsin and washing and remaining in the soluble fraction after sonication and centrifugation was interpreted to have been bound and internalized. Cbl-binding proteins elaborated by cultured fibroblasts into the culture medium were identified by gel filtration.

Immunoelectron microscopy. Ileal biopsies were preserved and prepared for electron microscopic examination as previously described (4). Sections were coded, and the examiner did not know which were from affected and which were from normal dogs. 
Statistical analysis. Results of breeding studies were assessed by the $\chi^{2}$ test. Serum $\mathrm{Cbl}$ concentrations of affected dogs and clinically normal littermates were compared by analysis of variance. Fecal $\left[{ }^{57} \mathrm{Co}\right]$ excretion data were compared using the Wilcoxon rank-sum test, and plasma radioactivity data were compared by analysis of variance for repeated measures.

\section{RESULTS}

Disease Manifestations. Clinical features. Detailed clinical and laboratory information about the proposita and another affected purebred giant schnauzer has been published previously (12). In those and all affected puppies subsequently studied, onset of clinical signs occurred between 6 and 12 wk. Most apparent were chronic inappetence and failure to thrive. Linear skeletal growth was normal or near normal, but affected puppies did not gain weight normally and were weak. Muscle mass was poorly developed and, by 4 mo of age, the puppies were cachectic. During intercurrent febrile episodes, they became anorectic and were markedly depressed.

Laboratory features. Absolute neutropenia $\left(0.66-3.8 \times 10^{9} / \mathrm{L}\right.$, littermate controls 5.2-11.6 $\times 10^{9} / \mathrm{L}$ ) developed in each affected puppy between 7 and 16 wk of age and was followed by development of nonregenerative anemia (packed cell volume 0.21 0.33 ; littermate controls $0.38-0.45$ ) that was evident by $20 \mathrm{wk}$ of age. Although erythrocyte Wintrobe indices were normal, blood smears revealed moderate to severe anisocytosis and poikilocytosis. Large ovalocytes, hypersegmented neutrophils, giant platelets, and occasional macrocytic and fully hemoglobinized normoblasts with immature nuclei were seen. Platelet numbers were normal. On bone marrow examinations, megaloblastic changes were particularly evident in the myeloid series. Giant metamyelocytes and band forms (Fig. 1) were present. Erythroid precursors were reduced in number, and cellularity of the marrow was normal or decreased. Bone marrow iron stores appeared normal, and serum iron concentrations and total iron-binding capacities were normal. Serum IgG concentrations were low (1.1-4.2 g/L, age-matched normal controls $10-25 \mathrm{~g} / \mathrm{L}$ ) but serum $\mathrm{IgA}$ and IgM concentrations were normal.

Before weaning at $1 \mathrm{mo}$ of age, serum $\mathrm{Cbl}$ concentrations of less than $75 \mathrm{pmol} / \mathrm{L}$ were noted in all puppies, three affected and seven obligate heterozygotes, born in $F_{1}$-backcross litters when the bitch, the proposita, had not been supplemented with parenteral $\mathrm{CN}-\mathrm{Cbl}$ during the last two trimesters of gestation or during lactation. After weaning, serum Cbl concentrations of the heterozygous puppies rapidly increased to above $150 \mathrm{pmol} / \mathrm{L}$, but those of the affected puppies remained $<75 \mathrm{pmol} / \mathrm{L}$. In the $\mathrm{F}_{2}$ litter raised by an obligate heterozygote bitch, only the affected puppy had a low serum $\mathrm{Cbl}$ concentration before or after weaning. At $8 \mathrm{wk}$ of age ( $3 \mathrm{wk}$ postweaning), affected puppies of all litters had significantly lower serum $\mathrm{Cbl}$ concentrations (all $<75$ $\mathrm{pmol} / \mathrm{L}, n=7)$ than clinically normal littermates $(203 \pm 11$ $\mathrm{pmol} / \mathrm{L}, n=11, F_{1,17}=49.66_{1}, p<0.0001$ ). Clinically normal, obligate heterozygote puppies had serum $\mathrm{Cbl}$ concentrations that were not significantly different from those of unrelated normal dogs (150-375 pmol/L). Serum folate concentrations were nor$\mathrm{mal}$ in all puppies throughout these studies. Low serum $\mathrm{Cbl}$ concentrations reported here are expressed as $<75 \mathrm{pmol} / \mathrm{L}$ because that was the $\mathrm{Cbl}$ concentration of the lowest standard in the radiobinding assay used. Serum $\mathrm{Cbl}$ concentrations were undetectable in samples from untreated affected puppies when checked by the more sensitive microbiologic assay using Euglena gracilus (data not shown).

Urinary organic acid analysis revealed metabolites of alternative pathways of propionyl-CoA catabolism in Cbl-deficient puppies. Large amounts of MMA and smaller amounts of methylcitrate, 3-OH propionic acid, and propionylglycine were present. Methylmalonic aciduria in Cbl-deficient puppies ranged from 4.0 to $46 \mathrm{~mol} \mathrm{MMA} / \mathrm{mol}$ creatinine. Clinically normal littermates and unrelated age-matched control puppies excreted less

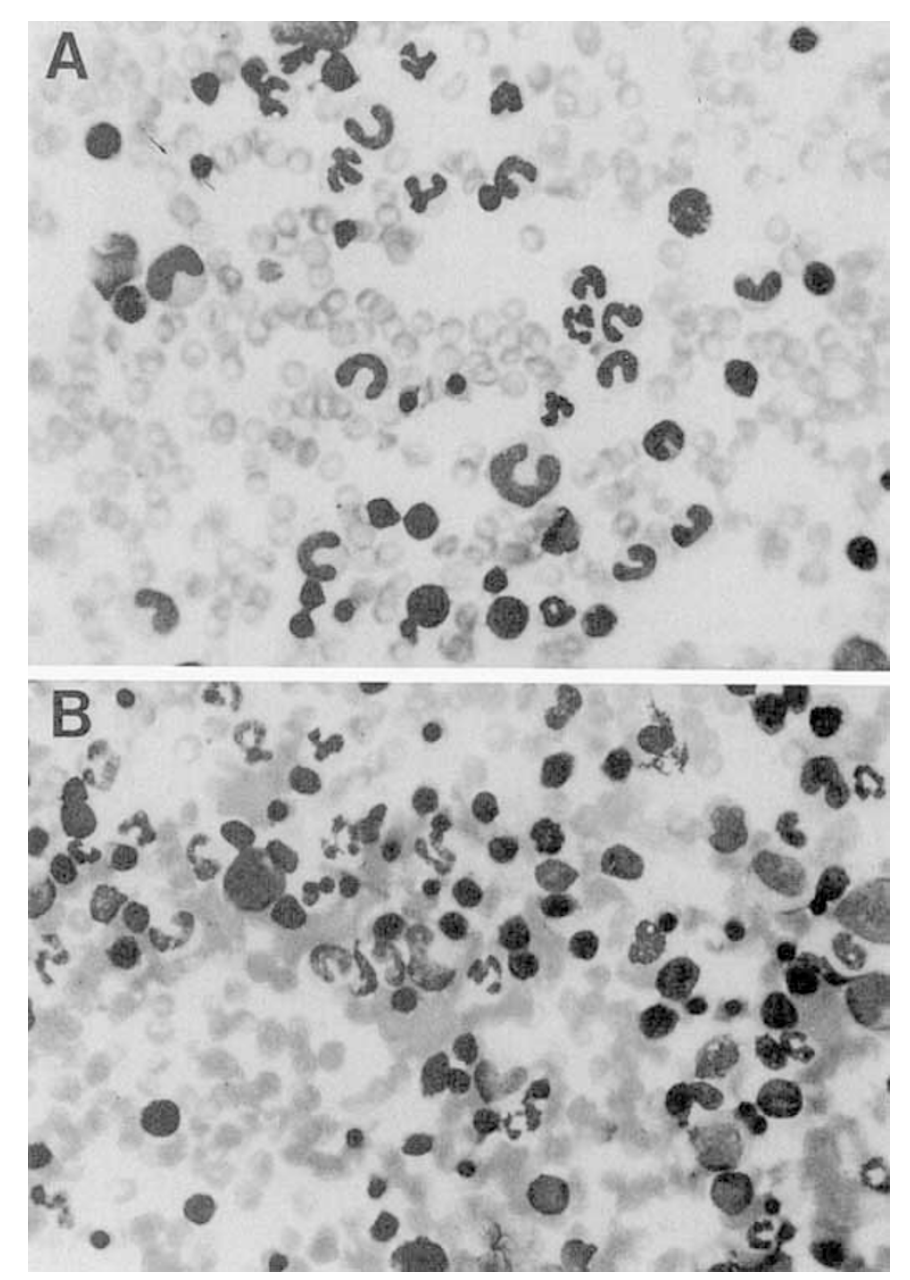

Fig. 1. Bone marrow aspirate from a Cbl-deficient and an agematched normal puppy. $A$, a typical aspirate from a 20 -wk-old, untreated, affected puppy exhibiting clinical and laboratory signs of $\mathrm{Cbl}$ deficiency. Megaloblastic changes are visible in some of the myeloid cells shown. Giant metamyelocytes and band neutrophils are present. Erythroid precursors are lacking and cellularity of the marrow is reduced from normal. $B$, a normal bone marrow aspirate is presented for comparison.

than $0.034 \mathrm{~mol} \mathrm{MMA} / \mathrm{mol}$ creatinine. Methylmalonic aciduria was noted before weaning in all puppies that were raised by a Cbl-deficient affected bitch, the proposita. After weaning, significant methylmalonic aciduria was present only in affected puppies (Fig. 2). In an $F_{2}$ litter whelped and raised by a clinically normal, obligate heterozygote bitch, on ' the affected puppy had methylmalonic aciduria before or after weaning.

Free amino acid concentrations in serum and urine from untreated, affected dogs were within normal limits. However, serum THCys concentration was elevated $(23.0 \mu \mathrm{mol} / \mathrm{L}$; normal adult dogs $6.3 \pm 1.4 \mu \mathrm{mol} / \mathrm{L}$, mean $\pm \mathrm{SD}, n=10$ ) in the proposita at $3 \mathrm{y}$ of age. At that time, the dog had not had parenteral $\mathrm{CN}$-Cbl treatment for $3 \mathrm{mo}$ and her serum $\mathrm{Cbl}$ concentration was $<75 \mathrm{pmol} / \mathrm{mL}$, but she was showing no clinical signs of $\mathrm{Cbl}$ deficiency. One mo subsequent to parenteral $\mathrm{CN}$ Cbl treatment ( $740 \mathrm{nmol} \mathrm{CN-Cbl/d} \mathrm{for} 7 \mathrm{~d}$ ), her serum THCys concentration was $6.1 \mu \mathrm{mol} / \mathrm{L}$.

In urine samples of sp gr 1.035-1.050 from $\mathrm{CN}-\mathrm{Cbl}$ treated and untreated affected dogs, $2^{+}$protein was consistently found by a qualitative colorimetric dipstick technique. This, however, was not considered abnormal for dogs with concentrated urine. In more quantitative studies, protein to creatinine ratios were consistently less than 0.4 in affected dogs (normal 0.08-0.54), and per $\mathrm{kg}$ body weight $24 \mathrm{~h}$ protein excretion determinations $[7-12 \mathrm{mg} /(\mathrm{kg} \cdot \mathrm{d})]$ using a sensitive quantitative method were 


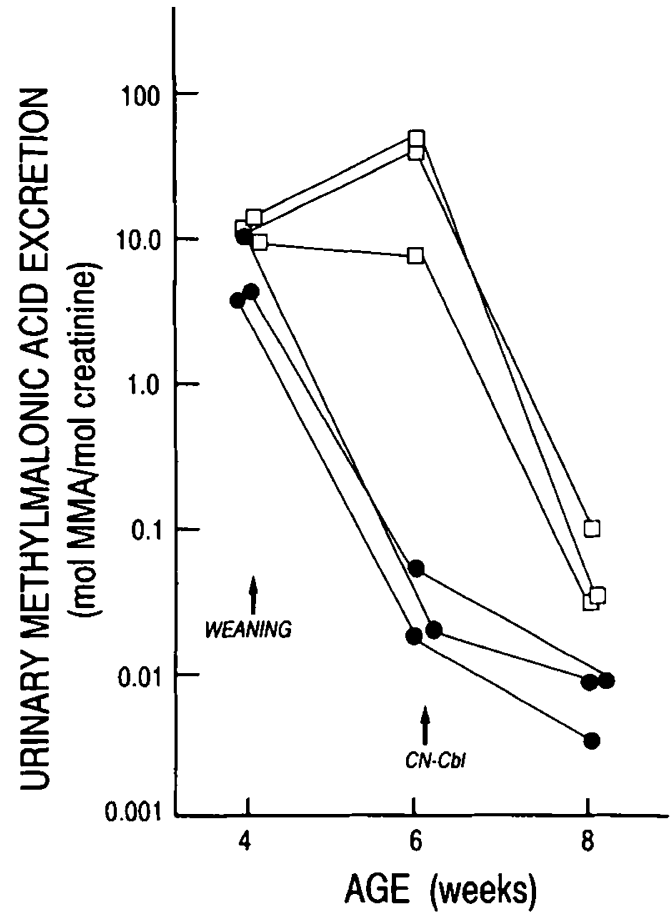

Fig. 2. Urinary MMA excretion. MMA concentrations of urine samples were measured by gas-liquid chromatography, and creatinine concentrations were measured by the picric acid method of Jaffe. The values shown are from urine samples obtained $1 \mathrm{~d}$ before weaning, $2 \mathrm{wk}$ postweaning, and $2 \mathrm{wk}$ after parenteral $\mathrm{CN}-\mathrm{Cbl}$ administration [740 nmol $(1 \mathrm{mg})$, intramuscularly, once). Three puppies $(\square)$ were affected with selective intestinal $\mathrm{Cbl}$ malabsorption, and three $(\bullet)$ were normal littermates. All six puppies were the offspring of an $F_{1}$-backcross mating, and the dam, the proposita of this study, was Cbl deficient during the latter part of gestation and during lactation.

repeatedly within normal limits for dogs [normal $13.9 \pm 7.7 \mathrm{mg}$ / $(\mathrm{kg} \cdot \mathrm{d})]$.

Response to treatment. As reported previously (12), no response was seen in a male affected puppy after $7 \mathrm{~d}$ of simultaneous parenteral folic acid administration $11 \mu \mathrm{mol} / \mathrm{d}(5 \mathrm{mg} / \mathrm{d})$ and oral CN-Cbl administration $7.4 \mathrm{nmol} / \mathrm{d}(10 \mu \mathrm{g} / \mathrm{d})$. However, affected puppies that were treated with a single intramuscular injection of $740 \mathrm{nmol}(1 \mathrm{mg})$ of $\mathrm{CN}-\mathrm{Cbl}$ had a rapid and complete resolution of all clinical, hematologic, and metabolic abnormalities except for persistent subnormal serum $\mathrm{Cbl}$ concentrations. Urine collected 10-60 min postinjection was pink (negative for blood or $\mathrm{Hb}$ ), suggesting that some of the administered $\mathrm{CN}-\mathrm{Cbl}$ was lost rapidly in the urine. Appetite and weight gain returned in 12 to $48 \mathrm{~h}$. All hematologic abnormalities resolved within 2 to 4 wk. Reticulocytosis $(0.024-0.106)$ began $3-4 \mathrm{~d}$ after parenteral $\mathrm{CN}-\mathrm{Cbl}$ administration and lasted for 10-14 d. MMA excretion decreased to $0.45-0.57 \mathrm{~mol} \mathrm{MMA} / \mathrm{mol}$ creatinine within $4 \mathrm{~d}$ of $\mathrm{Cbl}$ treatment and ranged between 0.014 and 0.113 $\mathrm{mol} \mathrm{MMA} / \mathrm{mol}$ creatinine for $8 \mathrm{wk}$ thereafter. Serum Cbl concentrations of these puppies were $150-375 \mathrm{pmol} / \mathrm{L}$ at $1 \mathrm{wk}$ after parenteral $\mathrm{CN}-\mathrm{Cbl}$ administration, but dropped below $75 \mathrm{pmol} /$ L by 2 wk posttreatment. A single $740-\mathrm{nmol}(1 \mathrm{mg})$ injection of $\mathrm{CN}-\mathrm{Cbl}$ in 8-wk-old affected puppies showing signs of $\mathrm{Cbl}$ defiziency was sufficient to support normal growth and prevent a relapse of clinical or laboratory abnormalities for $8 \mathrm{wk}$ despite subnormal serum $\mathrm{Cbl}$ concentrations. Eight to $10 \mathrm{wk}$ after treatment, the puppies relapsed with methylmalonic aciduria and srowth retardation. In six affected puppies 11-17 wk of age, zrowth retardation and methylmalonic aciduria were rapidly :eversed by daily s.c. administration of 1.9-3.7 nmol (2.5-5 $\mu \mathrm{g})$ of $\mathrm{CN}$-Cbl. Such treatment for $10 \mathrm{~d}$ prevented relapse for up to 1 wk. Affected dogs treated with $740 \mathrm{nmol}(1 \mathrm{mg}) \mathrm{CN}-\mathrm{Cbl}$ monthly remained healthy and grew to normal size and weight. Sperm production, ovarian cycling, and fertility were apparently normal in treated animals.

Pathology. A 19- and 28-wk-old affected puppy and a clinically normal, sex-matched littermate of each were euthanized. The older puppies had received $740 \mathrm{nmol}(1 \mathrm{mg})$ of $\mathrm{CN}-\mathrm{Cbl}$ parenterally at 8 wk of age, but the younger puppies had had no $\mathrm{Cbl}$ treatment. A third untreated, affected puppy died suddenly at 24 wk of age. All affected puppies were inappetent and had been losing weight daily at the time of death. Gross and histopathologic findings in the affected dogs were emaciation and moderate to severe lymphoid depletion or hypoplasia of the thymus, lymph nodes, and gastrointestinal lymphoid follicles. One had moderate diffuse atrophy of the gastric mucosa, and all affected puppies had mild to moderate diffuse atrophy of the duodenal and proximal jejunal mucosa and mild to moderate mucosal edema and lymphangiectasia of the entire intestinal tract. Many lymph node macrophages contained phagocytized erythrocytes and hemosiderin, and bone marrow contained mild to moderate amounts of hemosiderin. The bone marrow was hypocellular with scattered aggregates of megaloblastic erythroid and myeloid cells. Small numbers of normally maturing erythrocytes and myelocytes and normal numbers of megakaryocytes were present. No abnormalities were noted in the central or peripheral nervous systems. No significant gross or histopathologic lesions were found in the clinically normal littermates. Examination of biopsy specimens from 28 -wk-old affected dogs that were in hematologic and metabolic remission after parenteral $\mathrm{CN}-\mathrm{Cbl}$ administration revealed no histologic abnormalities of the gastrointestinal tract, lymph nodes, or bone marrow.

Genetic Studies. A pedigree of litters containing affected animals is shown in Figure 3. The proposita (no. 100), a purebred giant schnauzer, was the result of a father-daughter mating. Two male littermates (no. 105 and no. 106) had identical clinical and laboratory signs and were undoubtedly affected but were destroyed before studies of $\mathrm{Cbl}$ metabolism could be made. A related male giant schnauzer (no. 70) with a proven defect in $\mathrm{Cbl}$ absorption was the only affected puppy in a litter of six. In all, these two litters contained 16 puppies, four of which were affected (three of nine males and one of seven females). Both litters resulted from consanguineous matings between clinically normal parents, and all four parents shared a common ancestor (no. 30). From clinical descriptions by the breeder and the attending veterinarian, another male giant schnauzer (no. 51) sharing the same familial criteria was suspected to have had the same disease, but died before it could be studied. In a mating between two affected dogs (no. 100 and no. 70), all eight puppies (three male and five female) surviving the neonatal period were affected.

These findings strongly suggested autosomal recessive inheritance, and this hypothesis was tested by a series of experimental matings. Offspring were determined as affected when they exhibited growth failure, subnormal postweaning serum $\mathrm{Cbl}$ concentrations, hematologic abnormalities, methylmalonic aciduria, and rapid positive response to parenteral $\mathrm{CN}-\mathrm{Cbl}$ administration. The proposita was outcrossed to a normal male mongrel (no. 90) and produced an $F_{1}$ generation of nine puppies, eight of which survived the neonatal period, all clinically normal. Two of the $F_{1}$ offspring were mated and produced a litter of $10 F_{2}$ puppies; six survived the neonatal period, and one of these was affected. Normal $F$, males backcrossed to their affected dam produced three litters containing 17 surviving puppies, six of which (three male and three female) were affected. These results were consistent with inheritance of the disease as a simple autosomal recessive trait $\left(\chi^{2}=1.47, d f=1, p>0.25\right)$.

Laboratory Investigations. In all of the investigations described below, affected dogs studied or from which samples were derived had been treated with weekly injections of $740 \mathrm{nmol}(1 \mathrm{mg}) \mathrm{CN}$ $\mathrm{Cbl}$ and were in clinical, hematologic, and metabolic remission.

Cobalamin absorption tests. To test the hypothesis that affected dogs malabsorbed $\mathrm{Cbl}$, three affected dogs, a clinically normal 


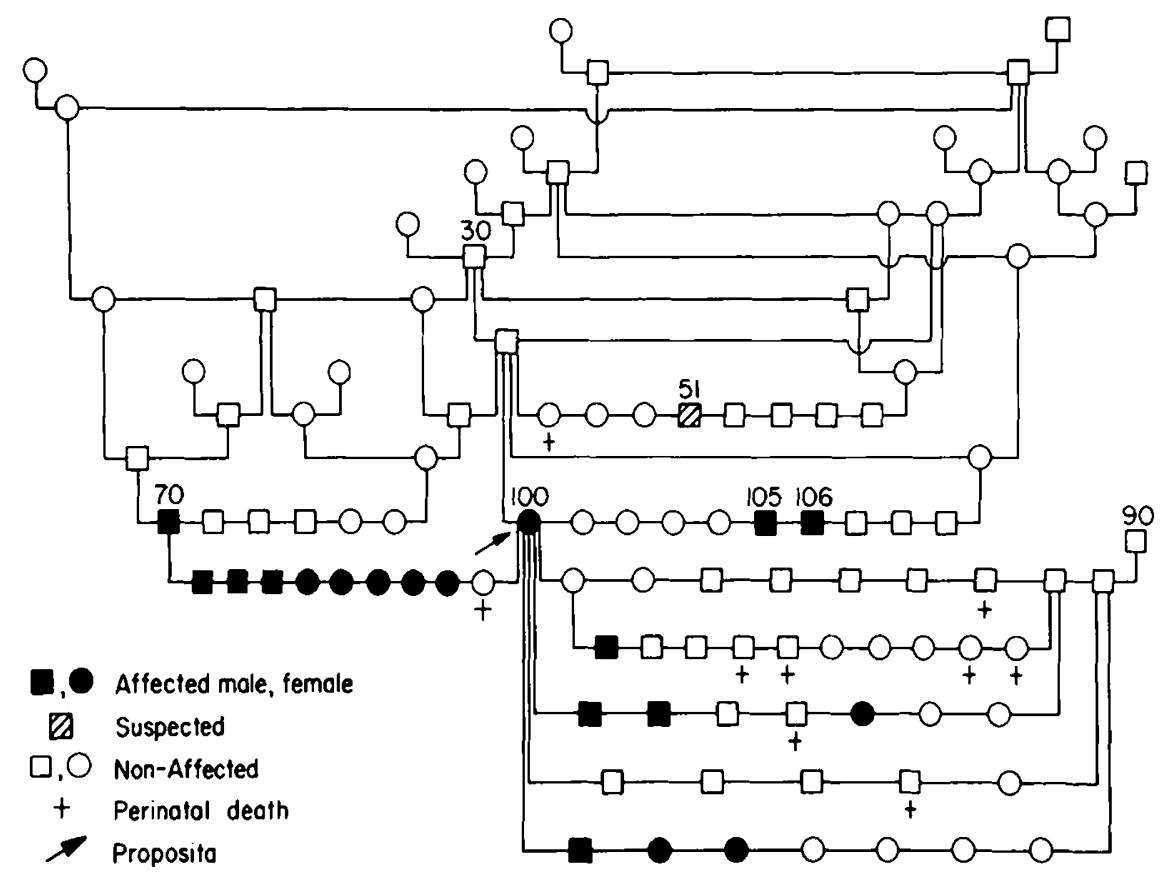

Fig. 3. Pedigree of a family of dogs with inherited selective intestinal Cbl malabsorption. A mating of two dogs is indicated by the symbols for offspring arranged on a horizontal line joining a vertical line from the bottom of the symbol for each parent. The proposita (arrow) and dog no. 70 were purebred giant schnauzers. Dog no. 90 was an unrelated, normal mongrel. Note that affected dogs were born to normal parents, that both sexes were affected, and that dog no. 30 is a common ancestor of every parent of an affected dog. These features and the numerical results of experimental outcross and $F_{1}$-backcross matings are consistent with simple autosomal recessive inheritance.

heterozygous dog, and five normal control dogs underwent $\left[{ }^{57} \mathrm{Co}\right]$ $\mathrm{CN}-\mathrm{Cbl}$ absorption tests. In phase I tests (Fig. 4), significant radioactivity was first detected in the plasma of control dogs 3 $4 \mathrm{~h}$ after oral administration of $\left.{ }^{57} \mathrm{Co}\right] \mathrm{CN}-\mathrm{Cbl}$ and was maximal at $6-7 \mathrm{~h}(0.013 \pm 0.003$ of administered dose, mean \pm SD $)$. Between 10 and $24 \mathrm{~h}$ postadministration, the $t_{1 / 2}$ of plasma radioactivity was $10.3 \mathrm{~h}$. In contrast, no radioactivity was detected in the plasma of affected dogs at any time point $(p<$ 0.0002 ). The same results were obtained in phase II tests; radioactivity was not detected in the plasma of affected dogs after oral administration of IF or normal dog gastric juice concurrent with

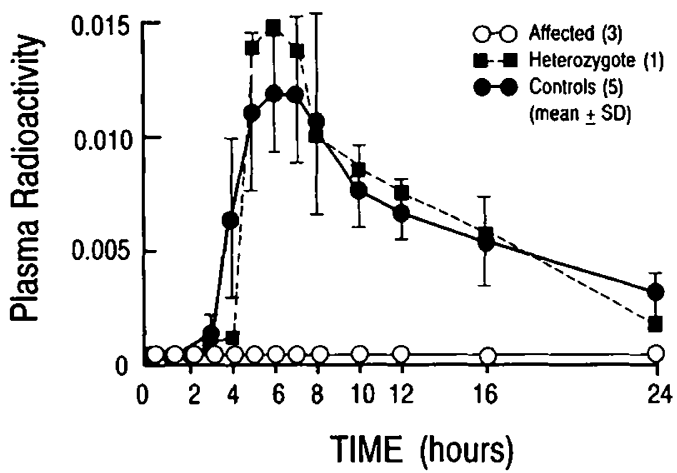

Fig. 4. Plasma radioactivity during phase $\mathrm{I}$ oral $\left[{ }^{57} \mathrm{Co}\right] \mathrm{CN}-\mathrm{Cbl}$ absorption tests. At time zero, $0.49 \mathrm{nmol}(0.67 \mu \mathrm{g})$ of $\left[{ }^{57} \mathrm{Co}\right] \mathrm{CN}-\mathrm{Cbl}(1.14 \mu \mathrm{Ci} /$ $\mathrm{nmol})$ was administered orally to each dog, and $740 \mathrm{nmol}(1 \mathrm{mg})$ of unlabeled $\mathrm{CN}-\mathrm{Cbl}$ was administered intramuscularly to each $\operatorname{dog} 2 \mathrm{~h}$ later. Values are expressed as the fraction of the administered dose in the total calculated plasma volume ( 0.05 of body weight). Solid circles and error bars indicate mean $\pm 1 \mathrm{SD}$ of the values obtained from five normal control dogs. In the affected dogs, plasma radioactivity was not detected at any time point. The heterozygote was not significantly different from control dogs. The same results were obtained when IF or normal dog gastric juice and $\left[{ }^{57} \mathrm{Co}\right] \mathrm{CN}$-Cbl were administered concurrently (phase II), suggesting an ileal enterocyte defect of $\mathrm{Cbl}$ absorption. the oral administration of $\left[{ }^{57} \mathrm{Co}\right] \mathrm{CN}-\mathrm{Cbl}$. The temporal pattern and magnitude of $\left[{ }^{57} \mathrm{Co}\right] \mathrm{CN}-\mathrm{Cbl}$ absorption during phase $\mathrm{I}$ in the clinically normal, obligate heterozygote were similar to those during phase I tests in the normal control dogs. Oral administration of IF or gastric juice did not improve or suppress $\left[{ }^{57} \mathrm{Co}\right] \mathrm{CN}$ $\mathrm{Cbl}$ absorption during subsequent phase II tests in this dog.

In phase I tests, fecal recovery of radiolabeled $\mathrm{Cbl}$ in five control dogs was $0.65 \pm 0.13$ of the administered dose after $6 \mathrm{~d}$, indicating that at least 0.35 of the administered dose was absorbed. Most of the fecal radioactivity was recovered on $\mathrm{d} 1$ and 2 , but $0.04 \pm 0.02$ of the administered dose was recovered during d 4-6. In contrast, the three affected dogs excreted $0.88 \pm 0.05$ $(p<0.074)$ of the administered radioactivity within $2 \mathrm{~d}$, and only 0.002 was recovered during d 4-6 $(p<0.036)$.

IF studies. Gastric and pancreatic juices were collected from an affected and a normal dog. In unstimulated gastric secretions, the affected dog produced $11.1 \mathrm{pmol} \mathrm{IF} /(\mathrm{h} \cdot \mathrm{kg}$ body weight), and the normal dog produced $11.6 \mathrm{pmol} \mathrm{IF} /(\mathrm{h} \cdot \mathrm{kg})$. In both, IF represented about 0.1 of the UCBC. Pentagastrin-stimulated gastric acid secretion was normal in both dogs (23). In the 30min fraction, $16.4 \mathrm{~mL}$ of $0.1 \mathrm{M} \mathrm{NaOH}$ were required to neutralize $10 \mathrm{~mL}$ of the affected dog's gastric juice to $\mathrm{pH} 7.0$, whereas $17.2 \mathrm{~mL}$ were required for the normal dog's. In pancreatic juice, the affected dog produced $77 \mathrm{pmol} \mathrm{IF} /(\mathrm{h} \cdot \mathrm{kg}$ body weight $)$, and the normal dog produced $88 \mathrm{pmol} /(\mathrm{h} \cdot \mathrm{kg})$. IF represented $0.5-$ 0.6 of pancreatic juice UCBC in these two dogs.

IF was purified from gastric and pancreatic juice of both dogs by affinity chromatography on Cbl-Sepharose after blocking of non-IF Cbl-binding proteins with 1000 -fold excess of cyanocobinamide. Sephadex G-200 gel filtration of the prepared proteins from both dogs gave identical elution profiles, a single symmet rical peak with retention coefficient $\left(\mathrm{V}_{c} / \mathrm{V}_{\mathrm{o}}\right)$ of 1.58 correspond. ing to an apparent $\mathrm{M}_{\mathrm{r}}$ of 66000

The purified pancreatic IF of each dog was assayed for IF-Cb binding to Triton X-100 extracts of homogenates of jejunal anc ileal mucosal biopsies from a normal dog. There was no IF-Cb binding activity of either in jejunal extracts. In ileal extracts both affected and normal dog IF exhibited specific IF-Cbl binding 
that was $\mathrm{Ca}^{2+}$ and $\mathrm{pH}$ dependent, binding being inhibited by 10 mM EDTA, pH below 6.0 or above 9.0 , or by 1000 -fold excess of unlabeled IF-Cbl. One thousand-fold excess of free $\mathrm{Cbl}$, IF devoid of $\mathrm{Cbl}$, or the Cbl-binding protein of dog bile did not inhibit IF-Cbl binding of either normal or affected dog IF to ileal extracts. Affected dog serum did not inhibit either IF binding of $\mathrm{Cbl}$ or binding of the IF-Cbl complex to ileal extracts. Affected dog IF bound ileal extracts at $130 \mathrm{fmol} / \mathrm{mg}$ ileal protein, and normal dog IF bound at $147 \mathrm{fmol} / \mathrm{mg}$ protein. Dissociation constants were 0.46 and $0.53 \mathrm{nM}$, respectively.

Purified pancreatic IF of the affected dog was bound to $\left[{ }^{57} \mathrm{Co}\right]$ $\mathrm{CN}-\mathrm{Cbl}$ and put into an isolated ileal segment of an anesthetized normal dog. Radioactivity was detected in the portal plasma 90 min later and increased to 0.0092 of the administered dose in the total plasma volume at $4 \mathrm{~h}$ postadministration. No radioactivity was detected in the portal plasma for $4 \mathrm{~h}$ after free radiolabeled $\mathrm{Cbl}$ was placed in an isolated ileal segment in a control dog.

TC-II studies. No difference in serum Cbl-binding proteins was detected between affected and control dogs. The UCBC of three affected dogs' serum ranged from 1.39 to $1.98 \mathrm{nmol} / \mathrm{L}$, whereas those of two control dogs were 1.56 and $1.46 \mathrm{nmol} / \mathrm{L}$. In both affected and normal, more than 0.9 of protein-bound Cbl was eluted from a Sephadex-G200 gel filtration column in a single symmetrical peak with retention coefficient $\left(\mathrm{V}_{\mathrm{e}} / \mathrm{V}_{\mathrm{o}}\right)$ of $2.00-2.05$. These results are similar to those previously reported for canine serum Cbl-binding proteins, the major peak being TC-II (21). In assays using $\left[{ }^{57} \mathrm{Co}\right] \mathrm{CN}$-Cbl-labeled serum of an affected and a normal dog, no differences were seen in TC-II$\mathrm{Cbl}$ internalization and incorporation into intracellular soluble material by normal dog fibroblasts. The serum of the affected dog mediated uptake by normal dog fibroblasts of $39.8 \mathrm{fmol}$ $\left[{ }^{57} \mathrm{Co}\right] \mathrm{CN}-\mathrm{Cbl} / 10^{6}$ cells. The normal dog serum mediated uptake by the same normal dog fibroblasts of $41.5 \mathrm{fmol} / 10^{6}$ cells. Cultured fibroblasts of the affected and normal dogs released TC-II into the culture medium. There were no differences in hepatic uptake and biliary excretion of radiolabel after injection of $\left[{ }^{57} \mathrm{Co}\right] \mathrm{CN}-\mathrm{Cbl}$ bound to TC-II into the portal circulation of anesthetized affected and normal dogs (Fyfe JC, Simpson KW, unpublished observations).

Immunoelectron microscopy. Immunohistochemical examination of normal and affected dog ileal biopsies was done by electron microscopy using polyclonal rabbit antibody against IF$\mathrm{Cbl}$ receptor purified from dog ileum $(4,20)$. In the normal dog biopsy, immunoreactive material was seen on many intracellular membranes, in tubular vesicles, and in particular, in many microvillus pits of the apical brush border of villus tip enterocytes in all of the sections examined (Fig. 5). These findings were exactly as previously reported for dog ileum (4). In contrast, in the affected dog ileal biopsy, although immunostaining was present on the same intracellular structures, IF-Cbl receptor staining was never found on the apical microvillus surface membrane of villus tip enterocytes. These results suggest that the inherited trait causing selective $\mathrm{Cbl}$ malabsorption in this family of dogs is absence of IF-Cbl receptor from the apical brush border of the ileum.

\section{DISCUSSION}

This family of dogs exhibits inherited selective intestinal $\mathrm{Cb}$ malabsorption that causes life-threatening $\mathrm{Cbl}$ deficiency early n life. Family studies and breeding experiments demonstrated imple autosomal recessive inheritance of this trait. Clinical signs, ;erum $\mathrm{Cbl}$ concentrations, urinary MMA concentrations, and ${ }^{57} \mathrm{Co} C \mathrm{CN}-\mathrm{Cbl}$ absorption of obligate heterozygotes were not diferent from those of normal controls.

Malabsorption of $\mathrm{Cbl}$ in affected dogs was documented by ${ }^{57} \mathrm{CojCN}-\mathrm{Cbl}$ absorption tests in which plasma radioactivity in he control dogs was similar to that observed in dogs previously 21 ) and was comparable to levels in humans studied in a similar way (24). The observation that fecal excretion of small amounts of orally administered $\left[{ }^{57} \mathrm{Co}\right] \mathrm{CN}$-Cbl lasted significantly longer in control dogs than in affected dogs suggests that enterohepatic recirculation of $\mathrm{Cbl}$ occurring in normal dogs was interrupted in the affected dogs. The reported biologic $t_{1 / 2}$ of placentally derived (25) and parenterally administered (26) Cbl in dogs is 6-16 wk, much shorter than the $t_{1 / 2}$ of 11-14 mo reported for humans (27). Thus, in contrast to humans, onset of clinical and laboratory signs of $\mathrm{Cbl}$ deficiency in the 2nd and 3rd mo of life and rapid relapse after treatment are compatible with congenital $\mathrm{Cbl}$ malabsorption in dogs.

The complete and rapid response of affected dogs to parenteral $\mathrm{CN}-\mathrm{Cbl}$ administration as the sole treatment suggested that the absorptive defect was selective for Cbl. Gastrointestinal histology by light and electron microscopy was normal in $\mathrm{CN}-\mathrm{Cbl}$-treated affected dogs. Furthermore, gastrointestinal function studies in the proposita revealed no abnormalities beyond selective $\mathrm{Cbl}$ malabsorption (12). Clinical signs suggestive of more generalized malabsorption were not observed in any of the dogs reported here, nor was there laboratory evidence of achlorhydria or exocrine pancreatic insufficiency.

Although the molecular or cellular nature of the inherited defect in this canine family was not defined, the defect was localized to the ileal enterocyte because no abnormality of IF or TC-II was detected. Moreover, the immunohistochemical findings strongly implicate a defect of the ileal receptor for IF-Cbl complex, either of expression or function. Further studies are needed to confirm this conclusion.

The disease in this family of dogs closely resembles inherited selective intestinal malabsorption of $\mathrm{Cbl}$ in humans (ImerslundGräsbeck syndrome; McKusick catalogue no. 26110) (28). In both, Cbl deficiency is caused by failure of the ileal enterocyte to mediate transcytosis of $\mathrm{Cbl}$. It has been described in about 200 human patients worldwide and is inherited as a simple autosomal recessive trait $(8,8 \mathrm{a}, 10)$. Severe $\mathrm{Cbl}$ deficiency usually develops between 1 and 4 y of age. Patients in most families also exhibit proteinuria and/or amino aciduria that persists despite parenteral $\mathrm{Cbl}$ treatment and remission of all other abnormalities $(8,8 \mathrm{a}, 29,30)$. Although high amounts of $\mathrm{IF}-\mathrm{Cbl}$ receptor have been found in renal proximal tubular epithelium of humans, dogs, and rats (31), it is not yet clear why selective intestinal Cbl malabsorption and proteinuria are inherited together.

Reported amounts of proteinuria in Imerslund-Gräsbeck patients range from $0.013-1.46 \mathrm{~g} / \mathrm{d}$ (normal is $<0.2 \mathrm{~g} / \mathrm{d}$ ), most of which is albumin $(29,30)$. Normal values of urinary protein excretion for $35-\mathrm{kg}$ dogs, as were studied here, range up to 0.75 $\mathrm{g} / \mathrm{d}$ (15). For this reason, it was not clear from our studies whether the proteinuria seen in Imerslund-Gräsbeck syndrome patients was occurring in these dogs. Because the definition of this disease is only operational at this time, it is likely that the syndrome in humans may encompass many defects along the pathway of ileal enterocyte $\mathrm{Cbl}$ transcytosis, only some of which also cause proteinuria or amino aciduria. An obvious advantage of this canine model is that it is genetically defined at the disease locus, all of the affected animals having the same mutation. Notably, a study of proteinuric Imerslund-Gräsbeck patients in one family indicated an absence or dysfunction of the IF-Cbl receptor (32). These dogs may represent at least a subset of human families with selective intestinal $\mathrm{Cbl}$ malabsorption.

The dogs are also a spontaneously occurring, nonhuman model of $\mathrm{Cbl}$ deficiency. The metabolic abnormalities found in the affected dogs were similar to those found in Cbl-deficient humans and other species. $\mathrm{Cbl}$ deficiency in the inadequately treated proposita caused low serum $\mathrm{Cbl}$ concentrations and methylmalonic aciduria in her otherwise normal, heterozygous puppies until weaning, as has been reported in human infants nursed by strict vegetarians or mothers with untreated pernicious anemia $(33,34)$. In subsequent gestations, the proposita received more aggressive Cbl therapy, and only her affected puppies became Cbl deficient. 

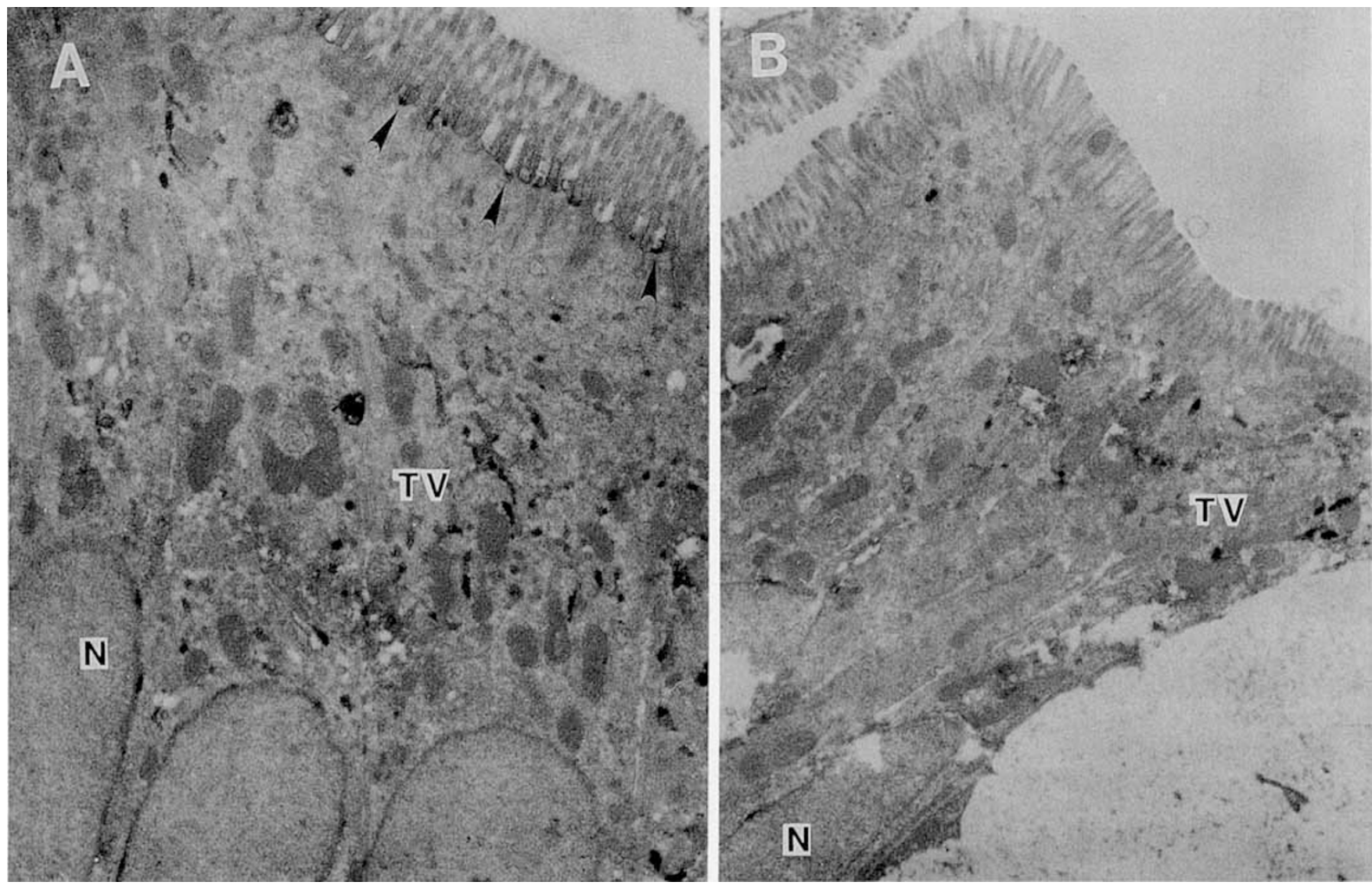

Fig. 5. Immunoelectron microscopy of ileal biopsy specimens from affected and normal dogs. The sections were stained by incubation with antidog IF-Cbl receptor antiserum and horseradish peroxidase. Villus tip enterocytes are shown. $A$, In the normal dog, immunocross-reactive receptor is present on many tubulovesicular membranes $(T V)$, the nuclear membrane $(N)$, and in many microvillus pits of the apical brush border (arrows) $\times 11000 . B$, In sections from dogs that could not absorb Cbl, immunocross-reactive receptor was present on the same intracellular membranes and in tubulovesicles as seen in normal dogs. However, receptor was never found on the apical microvillus surface membrane or in microvillus pits $(\times 8000)$. Receptor was not present in mucus-secreting cells of normal or affected dogs.

In the Cbl-deficient dogs, the proximal metabolites of Cbldependent enzymes accumulated and were metabolized by alternative pathways, producing abnormal organic acids and glycine conjugates that were excreted in urine. Untreated affected dogs excreted large amounts of MMA and smaller amounts of methyl citrate, 3-OH propionate, and propionylglycine. After parenteral $\mathrm{CN}-\mathrm{Cbl}$ treatment, affected puppies excreted only normal or slightly elevated amounts of MMA and no other abnormal organic acid metabolites. Stabler et al. (13) have discussed the difficulties caused by in vivo and in vitro disulfide formation of measuring serum homocysteine by routine ion exchange methods. In this study, elevated serum or urine concentrations of free homocysteine were not found in any of the untreated, affected dogs when measured by routine automated ion exchange techniques. However, in the affected dog studied by capillary gas chromatography-mass spectrometry with selected ion monitoring, serum THCys was elevated almost 4-fold above normal dog values and returned to normal after parenteral $\mathrm{Cbl}$ treatment.

The hematologic effects of $\mathrm{Cbl}$ deficiency in these dogs were similar to those in humans. Megaloblastic bone marrow is a hematologic hallmark of $\mathrm{Cbl}$ deficiency in humans (35) and was present in these dogs. Their bone marrow had more megaloblastic changes in myeloid cells than erythroid cells, and this was reflected in the peripheral blood. In humans, macrocytic anemia is a commonly recognized hematologic feature of $\mathrm{Cbl}$ deficiency. In the dogs, the presence of small numbers of macrocytic erythrocytes seen in peripheral blood smears was masked by the presence of numerous microcytic cells when assessed by Wintrobe indices.

Inappetence causing prolonged protein-calorie malnutrition or elevated concentrations of abnormal metabolites may have produced nonspecific abnormalities in blood cell production, morphology, and/or survival in these dogs. Additionally, gastrointestinal mucosal atrophy, lymphoid depletion or hypoplasia, and low IgG concentrations noted in the untreated, affected dogs were changes probably caused or exacerbated by protein-calorie malnutrition. We did not observe neurologic changes in Cbldeficient dogs analogous to subacute combined degeneration of the CNS in Cbl-deficient humans, monkeys, or fruit bats (3537). This may have been the result of species differences of $\mathrm{Cbl}-$ dependent metabolism or of insufficient duration of Cbl deficiency in the dogs.

This family of dogs represents a unique opportunity to address several central issues regarding intestinal $\mathrm{Cbl}$ absorption and $\mathrm{Cbl}-$ dependent metabolism in a genetically and phenotypically defined animal model.

Acknowledgments. The authors thank John R. Hansell, M.D. Veterans Administration Medical Center, Philadelphia, PA, for advice and technical support in the determination of fecal $\left[{ }^{57} \mathrm{Co}\right]$ excretion and serum $\mathrm{Cbl}$ concentrations; members of the Division of Biochemical Development and Molecular Diseases, The Children's Hospital of Philadelphia, for analyses of free serum and urinary amino acid concentrations and urinary organic acic quantitation; Robert H. Allen, M.D., and Sally P. Stabler, M.D. University of Colorado Health Sciences Center, Denver, CO, for serum THCys determinations; Kenneth W. Simpson B.V.M.\&S., Ph.D., School of Veterinary Medicine, University of Pennsylvania, Philadelphia, for surgical preparations; France: Shofer, Ph.D., University of Pennsylvania, Philadelphia, for sta. 
tistical data analysis; and James A. Begley, M.S., Veterans Administration Medical Center, Albany, NY, and Bellur Seetharam, Ph.D., Medical College of Wisconsin, Milwaukee, for valuable discussion and review of the manuscript.

\section{REFERENCES}

1. Fenton WA, Rosenberg LE 1989 Inherited disorders of cobalamin transport and metabolism. In: Scriver CR, Beaudet AL, Sly WS, Valle DV (eds) Stanbury JB, Wyngarrden JB, Fredrickson DS (consulting eds) The Metabolic Basis of Inherited Disease, 6th Ed. McGraw-Hill, New York, pp 20652082

2. Vaillant C, Horadagoda NU, Batt RM 1990 Cellular localization of intrinsic factor in pancreas and stomach of the dog. Cell Tissue Res 260:117-122

3. Batt RM, Horadagoda NU 1989 Gastric and pancreatic intrinsic-factor mediated absorption of cobalamin in the dog. Am J Physiol 257:G344-G349

4. Levine JS, Allen RH, Alpers DH, Seetharam B 1984 Immunocytochemical localization of the intrinsic factor-cobalamin receptor in dog-ileum: distribution of intracellular receptor during cell maturation. J Cell Biol 98:11111118

5. Spurling CL, Sacks MS. Jiji RM 1964 Juvenile pernicious anemia. N Engl J Med 271:995-1003

6. Katz M, Mehlman CS, Allen RH 1974 Isolation and characterization of an abnormal human intrinsic factor. J Clin Invest 53:1274-1283

7. Yang Y, Ducos R, Rosenberg AJ, Catrou PG, Levine JS, Podell ER, Allen RH 1985 Cobalamin malabsorption in three siblings due to an abnormal intrinsic factor that is markedly susceptible to acid and proteolysis. J Clin Invest 76:2057-2065

8. Imerslund O 1959 Idiopathic Chronic Megaloblastic Anemia in Children. Thesis. Oslo University Press. Oslo

8a. Imerslund O 1960 Idiopathic chronic megaloblastic anemia in children. Acta Paediat [suppl] 49:1-115

9. Gräsbeck R, Gordin R, Kantero I, Kuhlback B 1960 Selective vitamin $B_{12}$ malabsorption and proteinuria in young people. Acta Med Scand 167:289296

10. Ben-Bassat 1, Feinstein A, Ramot B 1969 Selective vitamin $B_{12}$ malabsorption with proteinuria in Israel. Israel J Med Sci 5:62-68

11. Hakami N, Neiman PE, Canellos GP, Lazerson J 1971 Neonatal megaloblastic anemia due to inherited transcobalamin II deficiency in two siblings. $N$ Engl $\mathrm{J}$ Med 285:1163-1170

12. Fyfe JC. Jezyk PF, Giger U, Patterson DF 1989 Inherited selective malabsorption of vitamin $B_{12}$ in giant schnauzers. J Am Anim Hosp Assoc 25:533539

13. Stabler SP, Marcell PD. Podell ER, Allen RH 1987 Quantitation of total homocysteine, total cysteine, and methionine in normal serum and urine using capillary gas chromatography-mass spectrometry. Anal Biochem 162:185-196

14. Bovee KC, Joyce $T 1979$ Clinical evaluation of glomerular function: 24-hour creatinine clearance in dogs. J Am Vet Med Assoc 174:488-491

15. DiBartola SP, Chew DJ, Jacobs G 1980 Quantitative urinalysis including 24hour protein excretion in the dog. J Am Anim Hosp Assoc 16:537-546

16. Batt RM, Horadagoda NU, McLean L, Morton DB, Simpson KW 1989 Identification and characterization of a pancreatic intrinsic factor in the dog.
Am J Physiol 256:G517-G523

17. Gottlieb C, Lau K, Wasserman LR, Herbert V 1965 Rapid charcoal assay for intrinsic factor (IF). gastric juice unsaturated $B_{12}$ binding capacity, antibody to IF, and serum unsaturated $B_{12}$ binding capacity. Blood 25:875-884

18. Begley JA, Trachtenberg A 1979 An assay for intrinsic factor based on blocking of the $\mathbf{R}$ binder of gastric juice by cobinamide. Blood 53:788-793

19. Allen RH, Mehlman CS 1973 Isolation of gastric vitamin $B_{12}$-binding proteins using affinity chromatography. J Biol Chem 248:3660-3669

20. Seetharam B, Alpers DH, Allen RH 1981 Isolation and characterization of the ileal receptor for intrinsic factor-cobalamin. J Biol Chem 256:3785-3790

21. Rappazzo ME, Hall CA 1972 Cyanocobalamin transport proteins in canine plasma. Am J Physiol 222:202-206

22. Hall CA. Colligan PD 1989 The function of cellular transcobalamin II in cultured cells. Exp Cell Res 183:159-167

23. Happé RP, DeBruijne JJ 1982 Pentagastrin stimulated gastric secretion in the dog (orogastric aspiration technique). Res Vet Sci 33:232-239

24. Arkun SN, Miller IF, Meyers LM 1969 Vitamin $B_{12}$ absorption test. Acta Haematol (Basel) 41:341-348

25. Luhby AL, Cooperman JM, Donnenfeld AM 1959 Placental transfer and biological half-life of radioactive vitamin $B_{12}$ in the dog. Proc Soc Exp Biol Med 100:214-217

26. Glass GBJ, Mersheimer WL 1958 Radioactive vitamin $B_{12}$ in the liver II Hepatic deposition, storage, and discharge of $\mathrm{Co}^{60} \mathrm{~B}_{12}$ in dogs. J Lab Clin Med 52:860-874

27. Schloesser LL, Deshpande $P$, Schilling RF 1958 Biologic turnover rate of cyanocobalamin (vitamin $B_{12}$ ) in human liver. Arch Int Med 101:306-309

28. McKusick VA 1988 Mendelian Inheritance in Man, 8th Ed. The Johns Hopkins University Press, Baltimore, pp 1129-1130

29. Broch H, Imerslund O, Monn E, Hovig T, Seip M 1984 Imerslund-Gräsbeck anemia; a long-term follow-up study. Acta Paediatr Scand 73:248-253

30. Rubin HM, Giorgio AJ, Macdonald RR, Linarelli LG 1974 Selective malabsorption of vitamin $B_{12}$ : report of a case with metabolic studies. Am J Dis Child 127:713-717

31. Seetharam B, Levine JS, Ramasamy M, Alpers DH 1988 Purification, properties, and immunochemical localization of a receptor for intrinsic factorcobalamin complex in the rat kidney. J Biol Chem 263:4443-4449

32. Burman JF, Jenkins WJ, Walker-Smith JA, Phillips AD, Sourial NA, Williams CB, Mollin DL 1985 Absent ileal uptake of IF-bound vitamin $B_{12}$ in vivo in the Imerslund-Gräsbeck syndrome (familial vitamin $\mathrm{B}_{12}$ malabsorption with proteinuria). Gut 26:311-314

33. Higginbottom MC. Sweetman L, Nyhan WL 1978 A syndrome of methyimalonic aciduria, homocystinuria, megaloblastic anemia and neurologic abnormalities in a vitamin $B_{12}$-deficient infant of a strict vegetarian. $N$ Engl $J$ Med 299:317-323

34. Sadowitz PD, Livingston A, Cavanaugh RM 1976 Developmental regression as an early manifestation of vitamin $B_{12}$ deficiency. Clin Pediatr (Phila) 25:369-371

35. Beck WS 1983 The megaloblastic anemias. In: Williams WJ, Beutler E. Erslev AJ. Lichtman MA (eds) Hematology, 3rd Ed. McGraw-Hill, New York, pp 434-465

36. Agamanolis DP Chester EM, Victor M, Kark JA, Hines JD, Harris JW 1976 Neuropathology of experimental vitamin $B_{12}$ deficiency in monkeys. Neurology 26:905-914

37. Green R, van Tonder SV, Oettle GJ, Cole G, Metz J 1975 Neurological changes in fruit bats deficient in vitamin $B_{12}$. Nature 254:148-150 